\section{Estimating the Economic Impact of the U.S. Golf Course Industry: Challenges and Solutions}

\author{
John J. Haydu ${ }^{1,4}$, Alan. W. Hodges ${ }^{2}$, and Charles R. Hall ${ }^{3}$ \\ Food and Resource Economics Department, University of Florida, Mid- \\ Florida Research and Education Center, 2725 S. Binion Rd., Apopka, FL \\ 32703-8504
}

Additional index words. IMPLAN, specialty crops, turfgrass, value added

\begin{abstract}
Compared with more traditional sectors of U.S. agriculture, little economic information is available on the turfgrass industry, of which golf courses are an integral part. As a result, over the past 30 years individual states have conducted over 60 individual studies that describe in detail the economic importance of their industry. To date, no such information exists at the national level primarily due to the high cost of collecting primary data. To ameliorate this situation, the authors used secondary data from various sources and developed a composite of the turfgrass industry for the entire United States. This report focuses on the golf course industry in particular. Golf represents a very high value amenity use of horticultural products and services, is a major form of development, and uses large amounts of land and water. Results indicate the golf sector is the largest component of the turfgrass industry, accounting for a $44 \%$ share. The nearly 16,000 golf courses generated $\$ 33.2$ billion (B) in (gross) output impacts, contributed \$20.6 $B$ in value added or net income, and generated 483,649 jobs nationwide. Economic impacts were also examined for each state, with "top 10" states highlighted. States falling in the top 10 category varied somewhat depending on the variables being examined. The exception were the top four states-Florida, California, Texas, and Illinois - that remained in the top four irrespective of variable type. In general, the top 10 states accounted for $55 \%$ to $60 \%$ of economic impacts for the entire United States while the top four alone contributed $40 \%$ of the total.
\end{abstract}

If a consumer survey of the general public were conducted today on the U.S. turfgrass industry, most people would likely know little about it. One could go even further by stating that many researchers and specialists in Land Grant Universities would also lack substantive knowledge about this increasingly important industry. A contributing factor is the relative scarcity of published economic information that is currently available. Unlike more traditional agricultural commodities, such as corn, soybeans, wheat, and cotton, where the U.S. Department of Agriculture has for decades collected detailed production and financial data (Foreman, 2001; Hoppe and Banker, 2006; Martinez, 2007), few resources have been directed at the turfgrass industry. This decision by the government to focus on the largest, most common areas of agriculture

\footnotetext{
Received for publication 10 July 2007. Accepted for publication 28 Nov. 2007.

${ }^{1}$ Professor.

${ }^{2}$ Associate-In, University of Florida, Food \& Resource Economics Department, Gainesville, FL 32611; e-mail awhodges@ufl.edu.

${ }^{3}$ Current address: Dr. Charles R. Hall, Ellison Chair in International Floriculture, Texas A\&M University, Department of Horticultural Sciences, 202 Horticulture/Forest Science Building, 2133 TAMU, College Station, TX 77843.E-mail: chall@ ag.tamu.edu.

${ }^{4}$ To whom reprint requests should be addressed; e-mail jjh@ifas.ufl.edu.
}

was largely cost-driven; it was simply too expensive to gather detailed information on the many hundreds of relatively minor "specialty crops" that were produced. However, in the past 15 to 20 years, the economic significance of specialty crops has grown appreciably, including nursery and greenhouse crops and turfgrass. Largely because of this increased significance, the USDA now undertakes broader studies that include nearly every specialty crop category. Some of the better-known studies on ornamental crops and turfgrass include the annual Floriculture and Nursery Crops Outlook (U.S. Department of Agriculture, 2005) and the Census of Agriculture, which covers all crops and livestock but only once every 5 years (U.S. Department of Agriculture, 2004). Although these studies have filled important voids in government statistics, due to their large numbers and the number of states producing them, the information collected on most specialty crops is largely limited to area under production and, in some cases, area harvested and annual sales.

In efforts to augment government data, many state trade associations representing specialty crops began initiating studies to document the economic significance of their respective industries. Incentives to do so include resource allocation concerns, government financial support, and regulatory actions that limit chemicals and fertilizers used in the production process. Competition for these natural and financial resources is felt in many parts of the country, but it is particularly acute in densely populated areas where farms and cities converge (Campbell and Sargent, 2001; Carriker, 1993; Haydu et al., 2004). As industries struggle to access more resources and the public becomes increasingly concerned over agricultural-related pollution, the need to document their importance is more crucial. Consequently, an abundance of "green industry" studies funded by state trade associations and conducted by University economists and horticulturists have recently been published. In fact, from 1978 to 2004, over 60 separate state-level studies on nursery crops and turfgrass were published (Hall et al., 2005). The scope of these publications and the methodologies employed vary widely, but all have a common theme of documenting the economic contribution of their particular industry. However, it has been this variability in objectives and approaches that has made it extremely difficult to extrapolate this information on a wider scale, such as regionally or nationally. Complicating the matter is the vast scope and complexity of the "Green Industry" itself. Also referred to as the "Environmental Horticulture Industry" and the "Nursery \& Greenhouse Industry", it is composed of a variety of businesses involved in the production, distribution, and services associated with ornamental plants, landscape, and garden supplies and equipment.

Recognizing the benefits of a comprehensive study encompassing all these relatively disparate groups, the authors conducted a national economic impact study of the "Green Industry" (Hall et al., 2005). Using the North American Industrial Classification System (NAICS), three major industry groups were examined representing 12 distinct subsectors. These groups and subsectors were: 1) Production \& Manufacturing (Nursery \& Greenhouse; Lawn \& Garden Equipment Mfg.; Greenhouse Mfg.); 2) Horticultural Services (Landscape Services; Landscape Architecture); and 3) Wholesale \& Retail Trade (Wholesale Flowers, Nursery Stock, Florist Supplies; Garden Equipment Wholesale; Lawn \& Garden Stores; Building Material Supply Stores; Florists; Food \& Beverage Stores; General Merchandise Stores). The significance of this study is that, for the first time, detailed economic information on the green industry exists at the national, regional, and state levels.

The turfgrass industry, in and of itself, is an important contributor to local economies, as was made clear in the numerous statesponsored studies conducted [e.g., Florida (Hodges et al., 1994), Texas and Mississippi (Lard et al., 1996; Richard et al., 1996), South Carolina (Rathwell et al., 1999), Georgia (Florkowski and Landry, 2000), and Pennsylvania (Willits and Shields, 2001)]. After the "Green Industry" study and in response to the numerous and often non-comparable state-level reports, Turfgrass Producers International (TPI) expressed interest in undertaking a national study. In mid-2004, TPI 
provided funding and an economic impact study of the U.S. turfgrass industry was undertaken covering five major sectors: sod farms, lawncare services, lawn and garden retail stores, lawn equipment manufacturing, and golf courses (Haydu et al., 2006). This paper presents updated results for the golf course industry to account for discrepancies in the original study, which are discussed below.

\section{Materials and Methods}

Data issues. Economic information for golf courses came from several sources. National-level information on the number of establishments, employment, and sales (receipts) was taken from the 2002 Economic Census Industry Report Series (U.S. Census Bureau, 2005). Sales figures represent total annual revenues from club memberships, daily playing fees, equipment rentals, and in some cases food services. In terms of club ownership, data included private, semiprivate, and public courses, and, regarding club size, the entire spectrum was represented (9-hole, 18-hole, and 27+-hole courses). This data were the most recent available at the time this study was undertaken. State-level information on the number of firms, employment, and payroll was taken from County Business Patterns (U.S. Census Bureau, 2004) and was adjusted to match the U.S. totals. For some states in which employment and wages were nondisclosed because of the small number of firms reporting, employment was estimated at the midpoint of the range indicated, and payroll was estimated at the national average annual wages per employee.

After delving into the research, a fairly large discrepancy emerged between U.S. Census figures on the number of facilities and those published by the National Golf Foundation (NGF). According to NGF, in 2002 there were 15,827 golf facilities nationwide (NGF, 2003). On the other hand, government census data lists a total of 11,836 golf courses in the country, a difference of roughly 4,000 units compared with the NGF data. Examination of the data indicates that this discrepancy is due to the definition of a golf course establishment used by the U.S. Census Bureau. According to their definition, an establishment is typically a "single physical location." Related to this, for establishments with multiple economic activities, firms were classified according to the dominant activity. For example, a golf course residing within an upscale commercial resort would not be recognized as a golf facility if it were a lesser economic activity than the overall resort complex. Therefore, the low number of golf courses reported in the Census was due to their classification under other industry sectors. As a result, on average, golf courses were under-represented by roughly $33 \%$ nationally. A related issue is that some states were under-represented more than others, specifically southern states with a higher proportion of commercial resorts. For instance, the discrepancy between U.S.
Census and NGF figures for Florida is $83 \%$, 2.5 times the national average (Table 1). Colorado (78\%), Arizona (53\%), and Utah $(89 \%)$ are examples of other states that were significantly under-represented by U.S. Census data. From the perspective of economic impact, states with high facility populations and large discrepancies (such as Florida) will have a substantially larger effect on total U.S. estimates than would states with smaller populations but large inaccuracies in the number of facilities (Utah).

To compensate for these discrepancies, economic impact estimates for each state were adjusted to account for the more accurate number of facilities reported by the NGF. This was accomplished by multiplying the original impact estimate by an adjustment factor shown in the third column in Table 1. The adjustment factor is calculated by dividing the NGF figures for the number of golf facilities (column 2) by U.S. Census figures (column 1). For example, FL with an original economic impact of $\$ 3.08 \mathrm{~B}$ was multiplied by 1.83 resulting in an adjusted value of $\$ 5.64$ B (2002 dollars). This higher value reflects the 486 Florida golf facilities not represented in the Census figures. Employment and value added impacts were also adjusted accordingly. Finally, because all original values were in 2002 dollars, these were further amended to reflect current dollars by using the Gross Domestic Product (GDP) Implicit Price Deflator (U.S. Department of Commerce, 2007) for Apr. 2002 and 2007.

Impact analysis. The economic data used for input-output analysis in IMPLAN is derived from the system of national accounts for the U.S. economy, based on periodic economic surveys conducted by the U.S. Commerce Department, U.S. Bureau of Labor Statistics, and other federal and state government agencies (MIG, Inc., 2004). Information that enters into the model includes industry outputs and inputs from other sectors, value added, employment, wages and business taxes paid, imports and exports, the mix of secondary products and by-products, final demand by households and governments, capital investment, business inventories, marketing margins, and inflation factors (deflators). These data are provided for 509 distinct industry sectors corresponding to the North American Industrial Classification System (NAICS), which are classified on the basis of the primary commodity or service produced. For this analysis, information was used for the IMPLAN sector "Amusement and Recreation Services." All the data are developed for every county in the United States, enabling construction of regional economic models at different levels of geographic aggregation, including individual counties, clusters of contiguous counties, individual states, or groups of states. Information on the technological mix of inputs for each industry sector is based upon nationallevel economic survey research; however, all other information is specific to the local region. IMPLAN also allows users to cus- tomize regional models based on original survey information.

To evaluate the broad regional economic impacts of the golf industry in the United States, regional economic models were developed for each state using the IMPLAN software system and associated state datasets (MIG, Inc., 2004). The IMPLAN system includes over 500 distinct industry sectors and was based on fiscal year 2001, the most recent secondary data available at the time. The information for these input-output models was derived from the U.S. National Income and Product Accounts, together with regional economic data collected by the U.S. Department of Commerce, Bureau of Economic Analysis. Input-output models represent the structure of a regional economy in terms of the numerous transactions that occur between industries, employees, households, and government institutions (Miller and Blair, 1985).

Economic multipliers derived from the models were used to estimate the total economic activity generated in each state from sales to final demand, together with exports. This includes the effects of intermediate purchases by industry firms from other economic sectors (indirect effects) and the effects of industry employee household consumer spending (induced effects), in addition to direct sales by industry firms. The regional IMPLAN models were constructed as fully closed models, with all household, government, and capital accounts treated as endogenous, to derive Social Accounting Matrix (SAM)-type multipliers, which represent transfer payments as well as earned income. Separate multipliers are provided for output (sales), employment, value added, labor income, and business taxes. The multipliers for output, value added, labor income, and indirect business taxes are expressed in units of dollars per dollar output, while the employment multiplier is expressed in jobs per million dollars of output. Differences in values of the multipliers reflect the structure of industry sectors and regional mix of supplier industries. The multipliers were applied to estimated industry sales or output to estimate total economic impacts. For golf courses, total economic impacts were estimated as

$$
\mathrm{I}_{\mathrm{hj}}=\mathrm{S}_{\mathrm{h}} \times\left[\mathrm{A}_{\mathrm{hj}}+\mathrm{E}_{\mathrm{h}} \times\left(\mathrm{B}_{\mathrm{hj}}+\mathrm{C}_{\mathrm{hj}}\right)\right],
$$

where $I_{h j}$ is total impact for measures (j) of output, employment, value added, labor income, or indirect business taxes in each state $(\mathrm{h}), \mathrm{S}_{\mathrm{h}}$ is industry sales in state $\mathrm{h}, \mathrm{A}_{\mathrm{hj}}$ is the direct-effects multiplier for measure $j$ in state $h, E_{h}$ is the proportion of industry sales exported or shipped outside the state by state $\mathrm{h}, \mathrm{B}_{\mathrm{hj}}$ is the indirect-effects multiplier for measure $\mathrm{j}$ in state $\mathrm{h}$, and $\mathrm{C}_{\mathrm{hj}}$ is the inducedeffects multiplier for measure $\mathrm{j}$ in state $\mathrm{h}$.

The calculation for the multiplier assumes that only the export portion of output is considered as exogenous final demand and, therefore, is subject to the indirect- and induced-effects multipliers, while the remainder of in-state sales is subject to intermediate 
Table 1. Economic impacts of golf course facilities, by state, $2002 .^{2}$

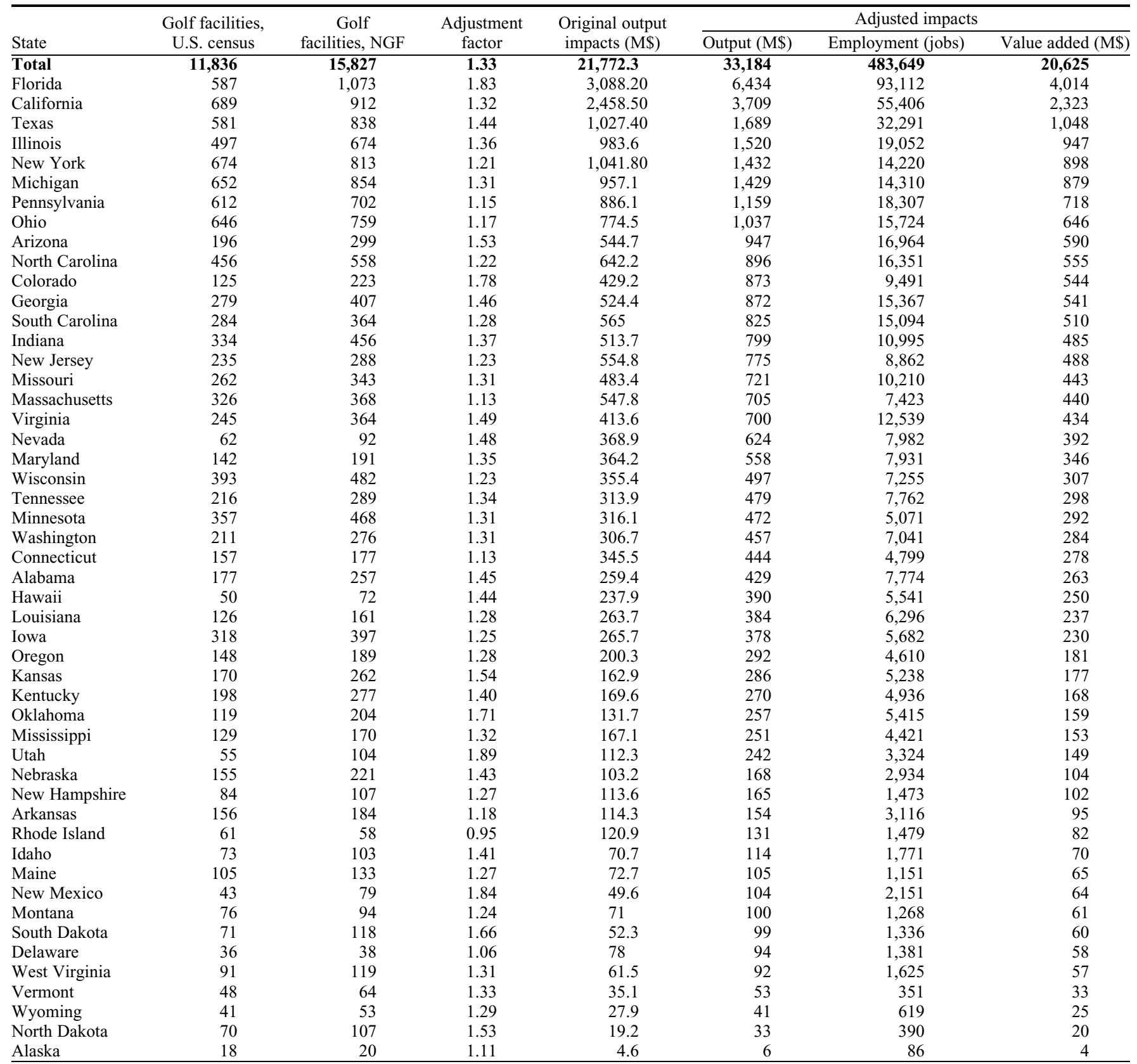

${ }^{\mathrm{z}}$ States listed by total (adjusted) output impact in descending order. Figures adjusted by the Implicit Price Deflator (U.S. Department of Commerce, 2007) to reflect 2007 dollars.

demand from other business sectors and to direct-effects multipliers. Exports for golf courses represent spending by out-of-state golf-playing visitors. Data on exports were taken from the IMPLAN database.

\section{Results and Discussion}

Original estimates of total economic impacts for the entire turfgrass industry were over $\$ 66$ B in 2002 but have been adjusted to reflect 2007 dollars (Table 2). This gross figure also included \$26 B in labor income, 822,848 jobs, and $\$ 2.7 \mathrm{~B}$ in indirect business taxes paid to local and federal governments. Finally, the turfgrass industry generated

Table 2. Original estimates of economic impacts of the turfgrass and lawncare industry in the United States, by sector, 2002. ${ }^{\mathrm{z}}$

\begin{tabular}{|c|c|c|c|c|c|c|c|c|}
\hline \multirow[b]{2}{*}{ Sector } & \multicolumn{4}{|c|}{ Output } & \multirow{2}{*}{$\begin{array}{l}\text { Value } \\
\text { added } \\
\text { (M\$) }\end{array}$} & \multirow{2}{*}{$\begin{array}{c}\text { Labor } \\
\text { income } \\
\text { (M\$) }\end{array}$} & \multirow{2}{*}{$\begin{array}{l}\text { Indirect } \\
\text { business } \\
\text { tax (M\$) }\end{array}$} & \multirow[b]{2}{*}{$\begin{array}{c}\text { Employment } \\
\text { (jobs) }\end{array}$} \\
\hline & $\begin{array}{l}\text { Total } \\
\text { (M\$) }\end{array}$ & $\begin{array}{l}\text { Direct } \\
(\mathrm{M} \$)\end{array}$ & $\begin{array}{c}\text { Indirect } \\
\text { (M\$) }\end{array}$ & $\begin{array}{l}\text { Induced } \\
\text { (M\$) }\end{array}$ & & & & \\
\hline Sod production & $1,903.0$ & $1,703.5$ & 32.9 & 166.6 & $1,443.4$ & 667.7 & 31.0 & 17,028 \\
\hline Lawncare services & $21,094.6$ & $14,602.8$ & $1,155.1$ & $5,336.5$ & $14,162.4$ & $11,038.6$ & 522.5 & 295,841 \\
\hline Lawn equipment manufacturing & $8,564.3$ & $7,008.1$ & 699.2 & 862.4 & $2,695.3$ & $1,395.5$ & 133.7 & 33,995 \\
\hline Golf courses & $24,816.5$ & $19,871.4$ & $1,073.5$ & $3,871.6$ & $15,424.3$ & $9,035.0$ & $1,305.8$ & 361,690 \\
\hline Total & $66,036.9$ & $47,208.3$ & $4,012.6$ & $14,821.3$ & $39,975.2$ & $26,257.7$ & $2,758.0$ & 822,848 \\
\hline
\end{tabular}

${ }^{\mathrm{z}}$ Figures adjusted by the Implicit Price Deflator (U.S. Department of Commerce, 2007) to reflect 2007 dollars. Source: Haydu et al. (2006). 
$\$ 35.1 \mathrm{~B}$ in value added. Value added is important because it represents a "net" figure after direct costs have been deducted. In this sense, value added is considered the most accurate estimate of an industry's contribution to an economy.

As mentioned earlier, golf courses were under-represented by roughly 33\% nationally. Using the unadjusted figures, golf courses were still the single largest component (44\%) in terms of economic impact for 2002 (Table 2). In that year, the 11,836 U.S. golf facilities identified by the U.S. Census generated $\$ 24.8$ B in output impacts, employed 361,690 people, and contributed $\$ 15.4 \mathrm{~B}$ in value added. This sector also provided $\$ 9.0 \mathrm{~B}$ in labor income and paid $\$ 1.3 \mathrm{~B}$ in indirect business taxes.

Information on adjusted estimates of economic impact using NGF data are shown in Table 1. According to NGF, the total number of golf course establishments nationwide was 15,827 in 2002 . The average number per state was 316; the fewest number (20) was in Alaska, while the greatest number $(1,073)$ was in Florida. California ranked second with 912 golf course establishments, followed by Michigan (854), Texas (838), New York (813), Ohio (759), Pennsylvania (702), Illinois (674), North Carolina (558), and Wisconsin (482). Combined, the top 10 states comprised nearly half $(45 \%)$ of all golf course establishments in the country.

As noted earlier, NGF estimates of facility numbers were used to adjust economic impacts nationwide. Adjustment factors ranged from a low of 0.95 for Rhode Islandmeaning the estimate was adjusted downward - to a high of 1.89 for Utah. Nationally, the average adjustment was 1.33 . Therefore, total output impacts for the golf course industry increased from $\$ 21.8 \mathrm{~B}$ to $\$ 33.2 \mathrm{~B}$. Of the five sectors examined in the turfgrass industry, golf now accounts for $44 \%$ of the $\$ 74.5$ B total (Fig. 1). Nationally, the golf course industry also contributed $\$ 20.6 \mathrm{~B}$ in value added and supported 483,649 jobs.

Total golf course output impacts for the top 10 states are illustrated in Fig. 2. Florida contributed the largest economic impact with $\$ 6.43 \mathrm{~B}$, followed by California with $\$ 3.71$ B. The remaining eight states had output impacts ranging from Texas with $\$ 1.69 \mathrm{~B}$ to North Carolina with $\$ 896 \mathrm{M}$. Combined, the

Economic impacts of turfgrass \& lawncare industry in U.S.

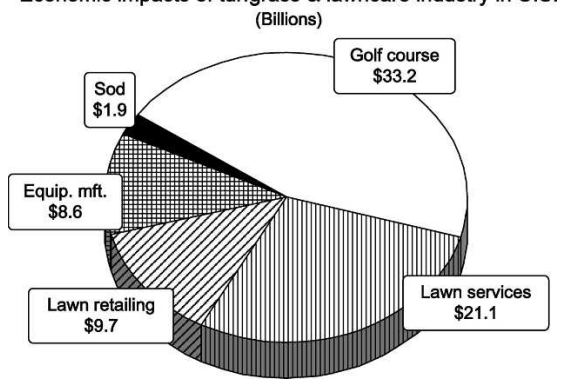

Fig. 1. Total output impacts for the turfgrass industry in the United States in 2002, adjusted for 2007 dollars. top 10 states contributed well over half $(58 \%)$ of total golf course output impacts in the United States in 2002. Finally, by dividing state-level impacts by the number of golf facilities, average impacts per facility can be generated. For the top 10 states, the average golf course establishment contributed $\$ 2.1 \mathrm{M}$ in output impacts while the range was a high of $\$ 6.0 \mathrm{M}$ for Florida to a low of $\$ 0.7 \mathrm{M}$ for Ohio.

Golf course employment figures for the top 10 states are shown in Fig. 3. Employment rankings differ somewhat from the

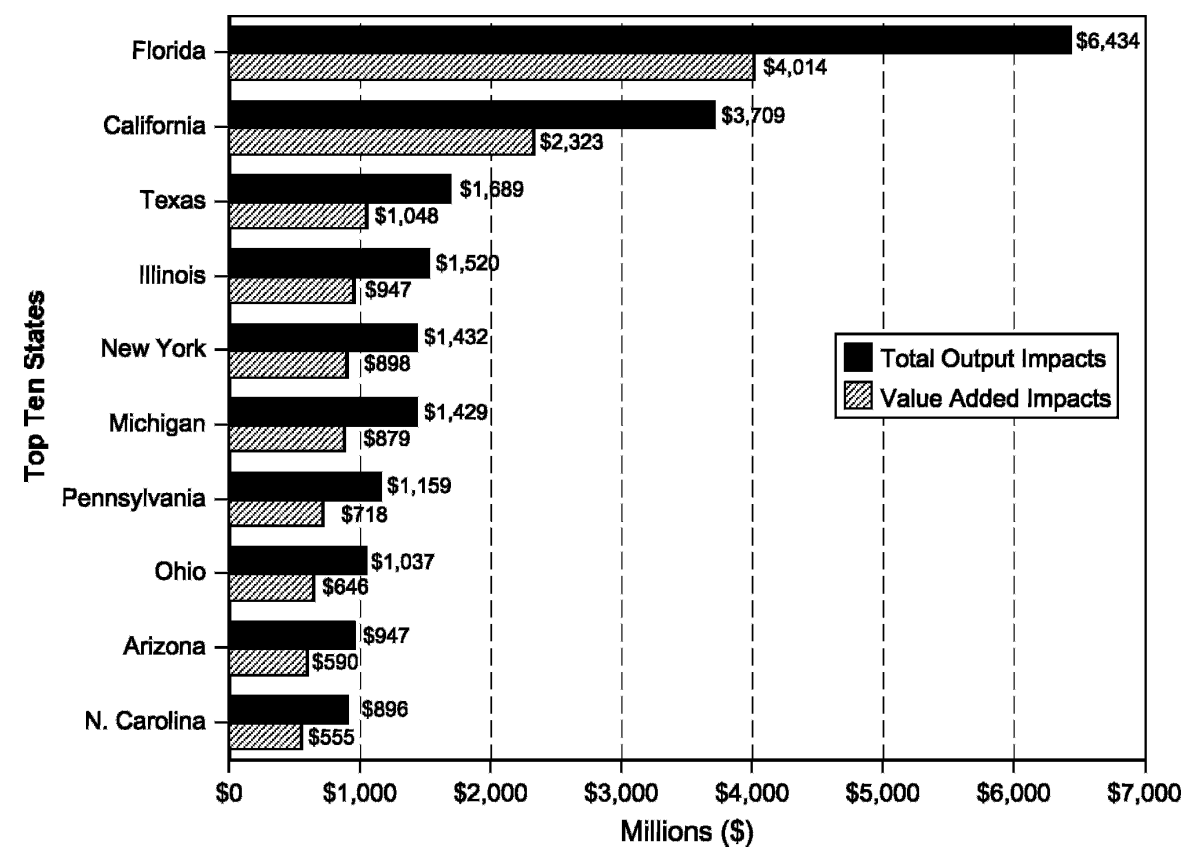

Fig. 2. Top 10 states of the golf course sector in 2002 for total output impacts and value added impacts, adjusted for 2007 dollars.

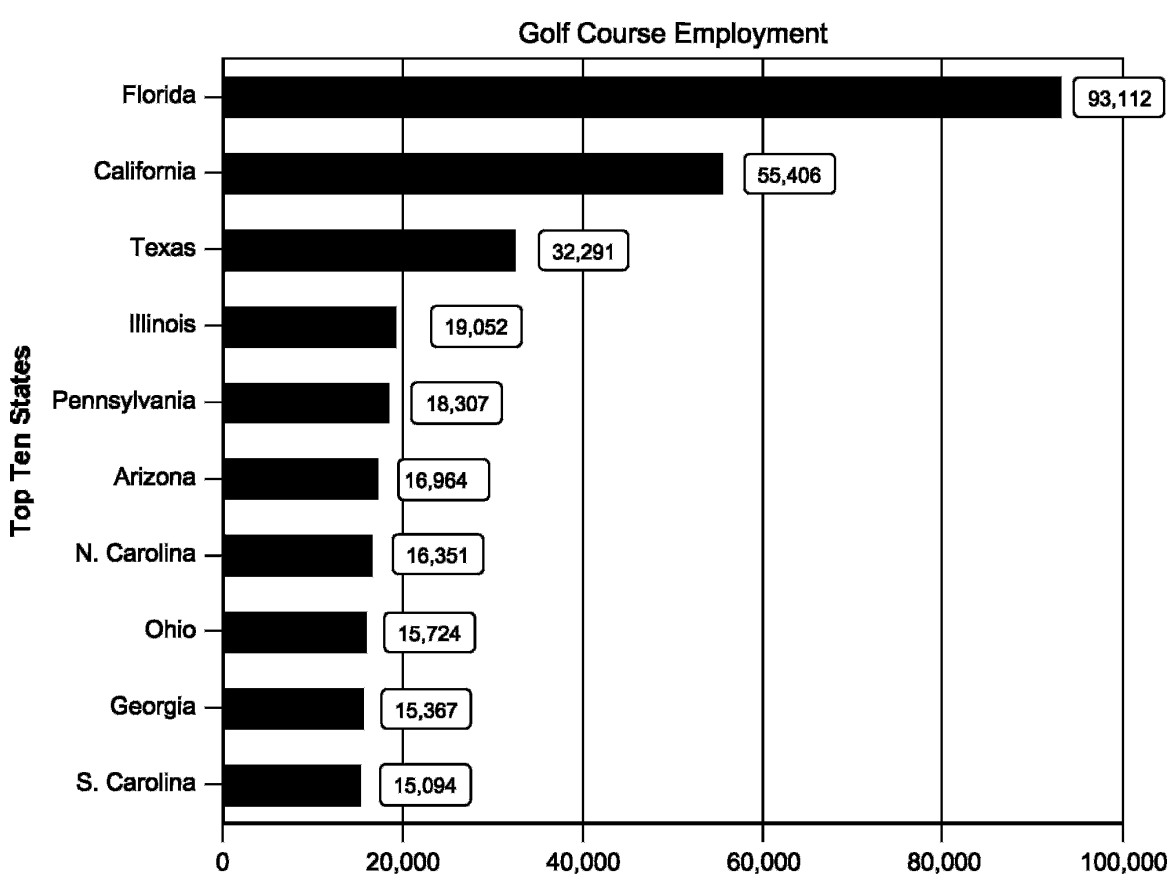

Fig. 3. Top 10 states for total employment impacts (jobs) of the golf course sector. output impact rankings discussed above. Florida $(93,112)$, California $(55,406)$, Texas $(32,291)$, and Illinois $(19,052)$ are still in the top four. Pennsylvania replaced New York for fifth and Arizona replaced Michigan for sixth, knocking it out of the top 10 category. Employment per facility varied considerably also. Florida averaged 68 people per course, compared with 57 for California and 35 for Texas. Pennsylvania, Illinois, North Carolina, and Ohio averaged between 20 and 28 employees per facility. Compared with these latter states, Arizona was quite high with an 
average of 50 people per facility. Several reasons might explain these differences with respect to employment. First, golf courses vary in terms of their size. Although the universal standard is 18 holes, many are only 9 holes, and some are 27 or more. Labor needs will be closely correlated with size of operation. Second, some facilities may have invested more heavily in capital to offset the increasing cost of labor. Golf courses with more automated irrigation systems and technologically advanced maintenance equipment would conceivably reduce labor needs. Third, some establishments may provide a larger array of member services, such as restaurants and bars, clubhouses, and lodging places that would require additional labor resources. Combined, the top 10 states contributed $61.2 \%$ of total golf course employment in the United States in 2002.

Estimates of the top 10 states for golf course value added are shown in Fig. 2. Statelevel rankings for value added are exactly the same as for output impacts. The top three states in value added were Florida (\$4.0 B), California (\$2.3 B), and Texas (\$1.0 B). The remaining seven states ranged from a high of $\$ 947 \mathrm{M}$ for Illinois to a low of $\$ 555 \mathrm{M}$ for North Carolina. Altogether in 2002 the top 10 states provided $60.8 \%$ of golf course value added in the United States.

Developing accurate estimates of a large industry's contributions to a state's economy is an expensive and time-consuming process, especially when little secondary data exists and one must rely on primary data. Researchers who have conducted the more than 60 state-level green industry studies over the past 30 years are well aware of these obstacles. From this perspective, trying to conduct a study national in scope would be far more daunting and cost-prohibitive, hence the need to employ more facile and less expensive methods. For this reason, several approaches were used that included both primary and secondary data as well as multiple public and private information sources.
The result is a comprehensive national study of the Golf Course Industry's contribution to the U.S. economy. In addition, impacts are presented at the state level, as well as the "top 10 " states for major indicators. Although this study is not perfect, its importance lies in the fact that it is a benchmark for which future studies can be compared. In this sense, research should be viewed as an iterative process where methodologies, data sets, and results improve over time.

\section{Literature Cited}

Campbell, R. and R. Sargent. 2001. Water crisis may strike here by ' 06 . The Orlando Sentinel Nov. 27:A1

Carriker, R.L. 1993. Agriculture, water quality, and public policy. Univ. of Florida, Inst. of Food \& Agr. Sci., Food Res. Econ. Dept., SP-96-15.

Florkowski, W.J. and G. Landry. 2000. An economic profile of the professional turfgrass and landscape industry in Georgia. The Georgia Agr. Expt. Stations, College of Agr. and Environ. Sci., The Univ. of Georgia, Res. Rep. 672.

Foreman, L. 2001. Characteristics and production costs of U.S. corn farms. USDA/ERS Stat. Bul. SB974-1.

Hall, C., A. Hodges, and J. Haydu. 2005. Economic Impacts of the Green Industry in the United States. USDA/NUCFAC Final report to the National Urban and Community Forestry Advisory Committee, 81 pages. <http://www.utex tension.utk.edu/hbin.greenimpact.html>.

Haydu, J.J., R.C. Beeson, and J. Caron. 2004 Economic analysis of five irrigation technologies for container-grown Viburnum odoratissimum. Acta Hort. 664:309-316.

Haydu, J.J., A.W. Hodges, and C.R. Hall. 2006. Economic impacts of the turfgrass and lawncare industries in the United States. <http:// www.economicimpact.ifas.ufl.edu/>.

Hodges, A.W., J.J. Haydu, P.J. Van Blokland, and A.P. Bell. 1994. Contribution of the turfgrass industry to Florida's economy, 1991/92: a value added approach. Food and Resource Econ. Dept., IFAS, Univ. of Florida, Econ. Rep. ER 94-1, 92 pp.

Hoppe, R.A. and D.E. Banker. 2006. Structure and finances of U.S. farms: 2005 family farm report. USDA/ERS Econ. Info. Bul. EIB-12.
Lard, C.F., C.R. Hall, and R.K. Berry. 1996. The economic impact of the Texas turfgrass industry. Dept. of Agr. Econ., College of Agr. and Life Sci., Texas A\&M University, Hort. Econ. Res. Rep. 96-9.

Martinez, S. 2007. The U.S. food marketing system: recent developments, 1997-2006. Econ. Res. Rep. ERR-42.

MIG, Inc. 2004. IMPLAN 2001, 50-State Data Package. MIG, Inc., Stillwater, MN.

Miller, R.E. and P.D. Blair. 1985. Input-output analysis: foundations and extensions. PrenticeHall, Englewood Cliffs, NJ, 464 pp.

National Golf Foundation (NGF). 2003. Number of U.S. golf facilities. Jupiter, FL. <http:// www.ngf.org/cgi/home.asp>.

Rathwell, P.J., M.G. Evatt, and M.S. Henry. 1999. Contributions of the ornamental horticulture and turfgrass industry to the South Carolina economy. Dept. Agr. and Appl. Econ., Clemson Univ., EER 194.

Richard, D.M., J.R. Field, J.M. Goatly, Jr., V.P. Shepard, and J.P. Sneed. 1996. The impact of the turfgrass industry on Mississippi's economy. Mississippi Agr. \& For. Expt. Sta., Mississippi State Univ., Bul. 1062.

U.S. Census Bureau. 2004. 2002 County business patterns, EPCD, County \& State Database on NAICS Basis. U.S. Dept. of Commerce, Washington, DC. Dec. 2004. <http://www.census. gov/epcd/cbp/view/cbpview.html>.

U.S. Census Bureau. 2005. 2002 Economic census industry report series for U.S. totals. U.S. Dept. of Commerce, Washington, DC.

U.S. Department of Agriculture, National Agricultural Statistics Service. 2004. 2002 Census of agriculture. U.S. Summary and State Data, Vol. 1, Geographic Area Series, Part 51, AC02-A-51. U.S. Dept. of Agr., Washington, DC.

U.S. Department of Agriculture. 2005. Floriculture and nursery crops outlook. FLO-04. <http:// usda.mannlib.cornell.edu/reports/erssor/ specialty/flo-bb/flo04.pdf>.

U.S. Department of Commerce. 2007. Gross domestic product: implicit price deflator, 1970-2007, quarterly. <http://research.stlouis fed.org/fred/data/gdp/gdpdef $>$.

Willits, F.K. and M. Shields. 2001. Pennsylvania's green industry: its nature and contribution to the state's economy. Dept. of Agr. Econ. and Rural Sociol., Pennsylvania State Univ., University Park, PA. 